(C) 2019Bezliudnyi.This article is distributed under the terms of CC Attribution-Share Alike 4.0 Internationalas described at https://creative commons.org/licenses/by-sa/4.0

UDC:376-053.6 (73)

DOI: $10.31499 /$

\title{
INCLUSIVE EDUCATION OF TEENAGERS WITH SPECIAL NEEDS IN THE UNITED STATES OF AMERICA
}

\author{
Roman Bezliudnyi \\ PhD in Education, Associate Professor \\ Pavlo Tychyna Uman State University, Uman, Ukraine \\ ORCID: 0000-0002-5687-2794; e-mail: oxo@ukr.net
}

The article deals with inclusive education of teenagers with special needs in the United States of America. According to the aim of the research the theoretical methods were used: analysis of academic and pedagogical works on the topic of the research, content analysis of research materials, followed by the synthesis of its results into a coherent system of views on the problem of inclusive education of teenagers with special needs in the USA.

The analysis of scientific and pedagogical literature reveals that American scientists believe that teenagers with special needs take advantage of full or partial inclusion in multiple school systems throughout the United States. Besides, they can receive special education services in correctional and developmental workrooms, where relevant specialists from the school's full-time staff work with them or this assistance can be given by specialists from counseling centers which function as separate institutions under the state departments of education. The author identifies the basic forms (occupational therapy, rehabilitation etc.) and methods (psycho-therapy, music therapy, art therapy, theatre therapy, hobby therapy, gardener therapy etc.) of teenagers' inclusive education in American educational institutions.

The author makes the conclusion that the American paradigm of the educational technologies application for the development of teenagers with special needs is based on the implementation of inclusive content through the introduction of various methods and forms. In general, the effectiveness of educational technologies for the teenager with special educational development in American educational institutions is ensured by the implementation of the inclusive content of education through the introduction of certain forms and methods of socio-pedagogical interaction between the individual and the social environment. The American experience in this regard is very useful for the reform of domestic special education.

Key words: inclusive education, teenagers with special needs, educational institutions, methods, social environment.

Стаття присвячена дослідженню проблеми інклюзивной освіти підліткіВ особливими потребами у Сполучених Штатах Америки. Аналіз наукової та педагогічної літератури показав, що американські науковиі зазначають, що підлітки з особливими потребами можуть користуватися повною або частковою інклюзією по всій території США в декількох шкільних системах. Крім того, вони можуть одержувати спеціальні освітні послуги у виправних та розвивальних 
приміщеннях, де з ними працюють відповідні фрахівці штатного персоналу, або така допомога може надаватися фрахівцями консультаційних иентрів, які функціонують як окремі установи при державних департаментах осъіти. Визначено основні методи (психотерапія, музична терапія, мистецька терапія, театральна терапія, хобі терапія, садівництво тощо) та форми (трудова терапія, реабілітація тощо) інклюзивноӥ освіти підлітків в американсъких навчальних закладах.

Автор робить Висновок, що американська парадигма застосування освітніх технологій для розВитку підлітків з особливими потребами базується на впровадженні інклюзивного контенту шляхом впровадження різних методів і форм. Загалом, ефективність освітніх технологій для під-літкіВ з особливими потребами В американських навчальних закладах забезпе-чується впровадженням інклюзивного змісту освіти через впровадження певних форм і методіВ сочіально-педагогічної взаємодії особистості та соціального середовища. Американсъкий досвід у цъому плані дуже корисний для реформи вітчизняної спеціальної осъіти.

Ключові слова: інклюзивна освіта, підлітки з особливими потребами, навчальні заклади, методи, сочіальне середовище.

Introduction. The development of modern society requires the formation of a new system for the inclusion of teenagers with special needs in the educational and rehabilitation process. In connection with this, there is a need for theoretical substantiation of a system of work with a special category of students - adolescents in American schools.

Inclusion of each child with special needs in the general education process and the implementation of various models of joint education in it, social and pedagogical adaptation in order to integrate a child into society are the main goals and objectives of inclusive education. Traditionally a common form of education for children with disabilities is special (correctional) education. At the same time, in practice, the process of integration of children with disabilities in the general education institutions is intensified, various models and forms of interaction between special and mass education are tested, and attempts are made to create adequate conditions for the fullest social adaptation and development of the child personality.

Analysis of recent research and publications. The issues of the inclusive education of teenagers with special needs, its content and nature were studied by domestic $(\mathrm{O}$. Bevz (issues of child giftedness in the school system), V. Bondar, A. Ilchenko and L. Saenko (the development of children with special needs in Montessori Method), A. Kolupayeva (development of inclusive education) and American scientists (S. Daren, M. Koh, S. Shin and others).

American society seeks for the most appropriate way in the education of children with special needs. The issue considering teaching students with and without disabilities in the same classroom as a best practice has become the most controversial topic in education (Koh, \& Shin, 2017).

Salend (2011) defines inclusive education as characterised by:

- a philosophy of acceptance and belonging within a community;

- philosophy of student, family, educator and community collaboration;

- celebration of the diversity and value of all learners;

- valuing educating learners in high-quality schools;

- valuing educating learners alongside their age peers;

- valuing educating learners in mainstream classrooms;

- valuing educating learners in schools in their local community.

Salend (2011) defines inclusive education as characterised by:

- a philosophy of acceptance and belonging within a community; 
- philosophy of student, family, educator and community collaboration;

- celebration of the diversity and value of all learners;

- valuing educating learners in high-quality schools;

- valuing educating learners alongside their age peers;

- valuing educating learners in mainstream classrooms;

- valuing educating learners in schools in their local community.

Salend (2011) defines inclusive education as characterised by:

$\checkmark$ a philosophy of acceptance and belonging within a community;

$\checkmark$ philosophy of student, family, educator and community collaboration;

$\checkmark$ celebration of the diversity and value of all learners;

$\checkmark$ valuing educating learners in high-quality schools;

$\checkmark$ valuing educating learners alongside their age peers;

$\checkmark$ valuing educating learners in mainstream classrooms;

$\checkmark$ valuing educating learners in schools in their local community.

Therefore, the aim of this paper is to provide a general overview of inclusive education of teenagers with special needs in the United States of America; to identify the basic methods and forms of teenagers' inclusive education in American edu-cational institutions.

According to the aim of our research, we used theoretical research methods: analysis of academic and pedagogical works on the topic of our research, content analysis of research materials, followed by the synthesis of its results into a coherent system of views on the problem of inclusive education of teenagers with special needs in the USA.

Presentation of the main research material. The United States is a country with a developed system of inclusive education. The issue of the integration of disabled children was first considered at the US Congress in 1973 and was enshrined in law. The main purpose of the law is to integrate the education of children with disabilities in general education schools with the provision of additional assistance. Since the 1980s the program «Inclusion» has been developed. The main goal of the program is to create all conditions for children with disabilities so that they can use the services in the same way as an ordinary person. Each institution must integrate all children, regardless of their social, emotional, psychological or other characteristics.

Inclusive education focuses on those children who have special needs and are included in an educational environment of «mainstream» schools. The Association for Supervision and Curriculum Development contends that the United States education system has segregated students who experience learning disabilities since roughly 1800. During the $19^{\text {th }}$ and $20^{\text {th }}$ centuries, students with learning disabilities received an education separate from nondisabled students.

Today, children take advantage of full or partial inclusion in multiple school systems throughout the United States. Schools that offer partial inclusion allow teenagers to participate in classrooms with nondisabled students during a day.

Daren $S$. believes that if a teenager needs services that may disrupt the class, they are taken to another classroom to complete their lessons for the day. For example, if a teenager requires intensive speech therapy, the school sets a separate room for students with special needs to complete their courses. Full inclusion means that teenagers collaborate with nondisabled students all day. In general, school systems attend to the needs of teenagers who have mild or severe learning disabilities (Daren, 2018).

Studying in schools of different directions, American teenagers with special needs can receive special education services in correctional and developmental workrooms, where relevant specialists from the school's full-time staff work with them or this assistance can be given by specialists from counselling centres which function as separate institutions under the 
state departments of education.

In American social practice, different levels of counselling are aligned.

The first level is informative when the consultant provides the client with the information he needs (for example, what is mental retardation or any other deviation in child development).

The second level of counselling is the development of different types of skill: behavioural, social, skills of elementary correction work. It takes a lot more than just providing information.

The third level is assistance in the active restructuring of the relationship assessment system of reality, and not just the provision of information or training.

There are social workers (school counsellors) in every American school (both regular and special).

The official statement of the American School Counselor Association (American School Counselor Association, 1998) defines the standards for providing social assistance to school counsellors. In essence, it outlines the scope of the main responsibilities of the school counsellor for the implementation of social support for children with special needs, such as:

$>$ the identification of children with special needs;

$>$ the identification of students' developmental and learning problems;

$>$ finding out the ways to meet needs;

$>$ a combination of group and individual counselling for teenagers with special needs;

$>$ recommending means for effective education and upbringing of such children;

$>$ implementation of professional guidance activities that help to select for teenagers with special needs the available future professions and recommendations for acquiring their professional knowledge and skills in relation to this profession.

School counsellors provide social support for teenagers with special needs in three dimensions: communication, activities and reflection (Van Tassel-Baska, 1998).

Efficient forms of educational technology for the development of life competencies of teenagers with special needs (in the spectrum of their socio-pedagogical rehabilitation) in the United States are:

A) occupational therapy.

American practices in the field of social work the term "occupational therapy» characterises as structured activities aimed at reducing the stresses of people with special needs and strengthening the belief in themselves, as well as training their interaction (communication) with other people, developing their daily life skills and professional work (Yarskaya-Smyrnova \& Naberushkyna, 2005). The main purpose of occupational therapy is the correction of the physical and psychological state of the disabled through the involvement in training their own skills and specific work activity.

B) sociotherapy.

Sociotherapy is a social science and form of social work and sociology that involves the study of groups of people, its constituent individuals and their behavior, using learned information in the case and care management towards holistic life enrichment or improvement of social and living conditions.

Important tools in sociotherapy are group classes, correspondence courses, distance learning courses, organization of holidays, the Internet and media resources etc. (Shumayeva, 2005).

C) occupational therapy.

It involves the implementation of therapy through daily classes and is a necessary component of effective assistance. Occupational therapy is an integrative part of a 
comprehensive program of medical, social, psychological and pedagogical rehabilitation and support (Kholostova \& Dementeva, 2004).

Specialists who work in this area are called «labour inspectors». They accelerate the development of underdeveloped or lost funds to perform certain labour functions. Such specialists are trained in institutions of higher education (for example, the University of Carolina at Chapel Hill, since 1976).

Occupational therapy begins with the functional diagnosis necessary to identify the degree of problems, ways and resources to overcome them. Together with the teenager and his family, other members of the team for the implementation of social support, the occupation therapist develops a rehabilitation plan, chooses the necessary resources and facilities.

The key element of occupational therapy is the choice of types of classes with a teenager, which are designed not only to form the necessary skills for the future independent professional existence, but also those that are appropriate to the personality of the adolescent.

Occupational therapy for teenagers with special needs allows improving the sensory and motor skills; increasing mobility, strength and endurance; stimulating health, productive relationships; getting the professional skills necessary for a decent future livelihood.

In the United States, occupational therapy, which is part of integrated social support programs for teenagers with special needs, is paid by powerful state programs and private insurance. In the private sector, there is a system of insurance funds from large corporations. Among federal government programs that fund occupational therapy in the United States, such programs as Vedicare, Medicaid, Civic Health Program (CHAMPUS), Mental Health Services Program etc. are functioning. The financing of occupational therapy is also provided for by normative and legal acts: the Law on Rehabilitation, the Law on the Education of the Disabled.

It should be noted that in Ukraine occupational therapy has not yet received its official status, but domestic scientists and practitioners recognize the great prospects of teenagers' with special needs social rehabilitation and support in this direction. During the rehabilitation work, various methods of therapeutic influence are used: psychotherapy, igotherapy, bibliotherapy, music therapy, art therapy, theater therapy, hobby therapy, gardenerotherapy etc. (Yarskaya-Smyrnova \& Naberushkyna, 2005).

Psychotherapy forms the feeling of children's self-confidence, educates their social, labour and aesthetic skills.

Artistic therapy (art therapy, isotherapy) is the transforming of the vision of the world and overcoming of children's experiences through painting.

Music therapy helps to stabilize the emotional state by means of sounds.

Hobby therapy allows teenagers to expand and improve their interaction with the outside world.

Gardener therapy (zootherapy) improves the communication of teenagers with nature, stimulates the child's desire and ability to listen, watch, study, understand their life experiences and gain self-confidence.

Relatively close and interrelated to the concept of socio-pedagogical rehabilitation is the notion of pedagogical correction of development, which began to be used in the world social pedagogy in late $19^{\text {th }}$ - early $20^{\text {th }}$ centuries under the influence of M. Montessori and O. Dekroli. At first, it was used only for work with mentally retarded children, and today it is applied for all categories of teenagers with special needs (Bondar \& Il'chenko, 2009). 
Correction of psychophysical development (Latin correctio-improvement, correction) in Ukrainian pedagogy means: a) a set of pedagogical and therapeutic means aimed at improving the integral process of development of the child; b) correction of individual defects in children with psychophysical disadvantages (Honeev, Lyfyntseva \&Yalpaeva, 2004).

For the realization of positive influences on the development of the personality of a teenager with special needs, through which some of his qualities can be corrected, the term «correctional and educational work» is used.

This work is realized in two interrelated directions: correction of deficiencies in different spheres of child development; promoting it further development as a holistic system (Kremen, 2008).

Correctional work in the United States relates to education and upbringing and permeates the entire system of specialist institutions for children with special needs (Shea, 1997). It is carried out in accordance with the developed curriculum and age characteristics of the child. Corrective measures are based on maximizing the use of the child's preserved capabilities, which gradually makes it possible to activate impaired or underdeveloped functions. Principal significance for the achievement of positive results of corrective and educational work in the development of the life competences of a teenager with special needs is to ensure the continuous effective links of a special school with a broad social environment of a teenager with special needs, as well as with other out-of-school educational institutions.

Conclusions. Thus, the analysis of the experience of inclusive education of teenagers with special needs in the United States of America has shown that inclusive education is a leading trend in the current stage of development of the American education system. As a result, a teenager with special educational needs has the right to get an education in any type of educational institution and receive the necessary specialized assistance. The American paradigm of educational techno-logy application for the development of teenagers with special needs life compe-tences is based on the implementation of inclusive content through the introduction of various methods and forms. In general, the effectiveness of educational techno-logies for the teenager with special educational development in American educa-tional institutions is ensured by the implementation of the inclusive content of educa-tion through the introduction of certain forms and methods of sociopedagogical interaction between the individual and the social environment. The American experience in this regard is very useful for the reforms in domestic special education.

Prospects for further scientific research are seen in the analysis of the specific forms and methods of inclusive special education support of American teenagers in educational institutions.

\section{References:}

1. American School Counselor Association (1998). Vision into action: Implementing the national standards for school counseling programs Fairfax, VA: American School Counselor Association.

2. Bondar V. I., Il'chenko A. M. (2009). Psykholoho-pedahohichni osnovy rozvytku ditey v systemi M. Montessori. Poltava: RVV PDAA.

3. Daren S. (2018). The Rise of Inclusion Education in the United States. Available at: http://www. specialneeds.com/children-and-parents/add/rise-inclusion-education-united-states.

4. Honeev A. D., Lyfyntseva N. Y., Yalpaeva N. V. (Eds.). (2004). Osnovy korrektsyonnoy pedahohyky. (3d ed.) M.: Academia.

5. Koh M., Shin S. (2017). Education of students with disabilities in the USA: Is Inclusion the answer? International Journal of Learning, Teaching and Educational Research, 16(10)1-17. Available at: https://doi.org/ 10.26803/ijlter.16.10.1. 
6. Kholostova E. Y., Dement'eva N. F. (Eds.). (2004). Sotsyal'naya reabylytatsyya. (2d ed.). M.: Yzd.-torh. korporatsyya «Dashkov y K».

7. Kremen V.H. (Ed). (2008). Entsyklopediya osvity. K.: Yurinkom Inter.

8. Shumayeva S. P. (2005). Rozvytok mas-mediynykh navchal'nykh tekhnolohiy u serednikh zakladakh osvity SHA. (Dys. of kand. ped. Nauk). Uman'.

9. Shea T. M. An Introduction to special Education. A social systems perspective (1997). Madison, 167.

10. Yarskaya-Smyrnova E. R., Naberushkyna E. K. (Eds.). (2005). Sotsyal'naya rabota s ynvalydamy. (2d ed.). SPB. y dr.: PYTER.

11. Van Tassel-Baska J. (Ed.). (1998). Counseling talented learners. Excellence in educating gifted and talented learners. Denver, CO: Love, 489-509.

Received: May, 11

Accepted: June, 2 